\title{
PENGARUH OPPORTUNISTIC BEHAVIOUR, LEVERAGE, FINANCIAL DISTRESS TERHADAP EARNINGS MANAGEMENT
}

\author{
Claudy Alfina ${ }^{1}$ \\ Universitas Pelita Harapan \\ ca70015@student.uph.edu \\ Elfina Astrella Sambuaga ${ }^{2}$ \\ Universitas Pelita Harapan \\ elfina_sambuaga@yahoo.co.id \\ Diterima 13 Februari 2021 \\ Disetujui 13 Juni 2021
}

\begin{abstract}
The purpose of this study is to examine the effect of opportunistic behavior, leverage, financial distress on earnings management. Samples were obtained from nonfinancial companies that reported financial reports in a row from 2010-2019 with a purposive sampling method, so as to obtain data as much as 232 observations. Earnings management is measured using the Kothari (2005) model, opportunistic behavior consisting of free cash flow (FCF) as measured by the Lehn \& Poulsen method (1989) and profitability as measured by Return on Assets (ROA), leverage is measured by Debt Ratio and financial distress. measured by Zmijewski's (1984) model during the study period. Data were tested using multiple linear regression through the STATA program. The results showed that opportunistic behavior as proxied by profitability can increase managers' motivation towards earnings management, as well as leverage. However, opportunistic behavior as proxied by free cash flow is not in accordance with predictions, while financial distress has no significant effect on earnings management.
\end{abstract}

Keywords: Earnings Management; Opportunistic Behaviour; Leverage; Financial Distress; Zmijewski Model

\section{PENDAHULUAN}

\subsection{Latar Belakang}

Kualitas informasi yang terkandung dalam laporan keuangan akan bermanfaat apabila informasi tersebut mampu menunjukkan keadaan perusahaan yang sebenarnya sehingga dapat digunakan dalam pengambilan keputusan. Salah satu informasi yang masih digunakan oleh para investor dalam pengambilan keputusan adalah laba. Hal ini memotivasi para manajer untuk mengambil kebijakan yang dapat meningkatkan angka laba, sehingga memperlihatkan kinerja perusahaan yang stabil. Manajemen laba (earnings management) sudah menjadi pusat perhatian yang cukup besar selama kurang lebih empat puluh tahun lamanya (Callao et al. 2017). Motivasi para majemen untuk melakukan manipulasi juga berhubungan dengan agency theory yang diamsusikan seperti sebuah kontrak antara para shareholders perusahaan sebagai principal yang mendelegasikan para manajer perusahaan sebagai agent untuk membuat keputusan terbaik kepada pihak principal. Salah satu hipotesis utama mengenai teori

${ }^{2}$ Corresponding Author 
keagenan menjelaskan bahwa setiap individu dari pihak shareholders maupun manajer memiliki motivasi untuk memaksimalkan kepentingan dirinya sendiri sehingga memunculkan konflik antara pihak shareholders dan manajer perusahaan. Situasi dalam kontrak tersebut memiliki ketidakseimbangan informasi yang berarti terdapat satu pihak yang memiliki informasi mengenai perusahaan yang lebih luas yaitu pihak manajer (Kazemia dan Sanusi, 2015). Motivasi yang tinggi untuk mementingkan diri sendiri dan ditambah ketidakseimbangan informasi yang diperoleh dari pihak manajer perusahaan lebih luas, dapat memengaruhi pelaporan laporan keuangan dengan melakukan manajemen laba. Pihak manajer akan memaksimalkan berbagai usaha untuk kepentingan pribadi mereka sehingga menimbulkan motivasi perilaku oportunistik.

Manajer yang memiliki motivasi perilaku oportunistik cenderung berupaya untuk menyamarkan informasi pada laporan keuangan, sehingga seolah-olah memiliki kinerja yang baik. Pada penelitian ini, oportunistik manajer dikaitkan dengan free cash flow dan profitabilitas perusahaan. Arus kas bebas (free cash flow) dapat memberikan peluang bagi manajer dalam melakukan investasi (Ghazali et al., 2015). Hal ini dikarenakan manajer memiliki pilihan untuk melakukan invastasi pada perusahaan dengan pengembalian yang tinggi atau sebaliknya. Apabila pilihan manajer dilakukan pada proyek dengan pengendalian investasi yang rendah, maka perusahaan akan berada dalam pertumbuhan yang rendah serta dapat berdampak pada menurunnya profit. Terkait dengan pilihan investasinya ini, hutang (leverage) termasuk salah satu instrumen yang dapat digunakan oleh perusahaan untuk membiayai aset perusahaan. Keberadaan hutang (leverage) juga dapat digunakan sebagai bentuk pengendalian agar perusahaan dapat terhindar dari manajemen laba yang dilakukan secara eksesif (Lisboa, 2017). Namun, keberadaan hutang dapat menjadi tekanan bagi manajer untuk agar kinerja perusahaan terlihat baik sebagaimana perjanjian batas hutang yang wajar, sehingga memotivasi manajer untuk melakukan earnings management (Ghazali et al., 2015; Suffian et al., 2015; Anggraeni dan Wardhani, 2017). Disisi lain, adanya hutang (leverage) perlu diperhatikan mengingat resiko yang timbul apabila perusahaan mengalami kesulitan dalam membayar hutang yang semakin tinggi. Kondisi ini dapat membawa perusahaan pada kesulitan keuangan (financial distress) yang dapat berujung pada kepailitan.

Pada penelitian ini, peneliti mengacu pada penelitian Ghazali (2015) namun menggunakan metode pengukuran Financial Distress yang berbeda, yaitu menggunakan model yang dikembangkan oleh Zmijewski (1984). Alasan penggunaan model ini, karena berdasarkan penelitian yang dilakukan oleh Ashraf et al. (2019) dan Wu et al. (2010) yang membandingkan model prediksi financial distress, model Zmijewski (1984) didapati lebih akurat dibandingkan dengan model prediksi financial distress lainnya seperti Altman (1968) dengan model Z-Score, Ohlson (1980) dengan model O-score, Zmijewski (1984) dengan teknik dan model probit, Shumway (2001) menggunakan teknik dan model Hazard, dan Blums (2003) yang menggunakan model D-score. Kontribusi penelitian ini ingin membuktikan adanya kekonsistenan hasil yang di perolah sesuai dengan penelitian Ghazali (2015) jika menggunakan metode financial distress yang terbukti lebih akurat, serta menggunakan data dari bursa pasar modal di Indonesia.

\subsection{Rumusan Masalah}

Manajer yang oportunistik juga dapat menyamarkan laporan keuangan perusahaan, seharusnya kinerja perusahaan yang dinilai buruk namun melaporkannya seolah-olah perusahaan memiliki kinerja yang tinggi. Pada penelitian ini, oportunistik manajer dikaitkan dengan arus kas bebas (free cash flow) dan profitabilitas perusahaan. Perusahaan yang memiliki arus kas bebas yang tinggi cenderung membuka peluang untuk manajer perusahaan 
melakukan manajemen laba dan juga menimbulkan masalah keagenan. Masalah tersebut akan terjadi ketika arus kas bebas yang tinggi diatur oleh manajer perusahaan untuk berinvestasi. Ghazali et al (2015). Para manajer memiliki pilihan untuk menginvestasikan ke perusahaan yang memiliki pengembalian tinggi ataupun ke perusahaan yang memiliki pengembalian rendah. Apabila manajer memilih pilihan untuk berinvestasi dengan pengembalian rendah, maka perusahaan berada dalam pertumbuhan yang rendah dan juga menurunkan profit. Ketika perusahaan mengalami penurunan dalam mendapat laba, manajer akan termotivasi untuk merekayasa pendapatan. Strategi lain yang dilakukan manajer untuk merekayasa pendapatan yaitu dengan mengatur leverage.

Leverage mengacu pada hutang yang digunakan oleh perusahaan untuk menjalankan operasionalnya dengan membiayai aset perusahaan. Semakin meningkat jumlah hutang yang digunakan perusahaan maka resiko yang perusahaan harus hadapi juga semakin tinggi. Resiko yang tinggi tersebut memotivasi manajemen perusahaan untuk menaikan pendapatan lebih tinggi agar terhindar dari terjadinya ancaman likuiditas dan menggunakan manajemen laba untuk mengurangi biaya hutang. Di sisi lain, leverage juga dapat digunakan oleh perusahaan sebagai pengendalian mekanisme (monitoring mechanism) agar perusahaan dapat terhindar dalam melakukan manajemen laba secara eksesif (Lisboa 2017). Namun perlu diperhatikan apabila perusahaan yang memiliki leverage yang tinggi tidak ditangani dengan benar maka resiko perusahaan mengenai kesulitan dalam membayar hutang juga semakin tinggi, dan perusahaan bisa mengalami financial distress yang berujung kebangkrutan.

Financial distress merupakan kondisi perusahaan ketika mengalami kesulitan dalam keuangan. Perilaku manajemen laba juga memiliki keterkaitan yang erat dengan kondisi financial distress dimana perusahaan yang mengalami kondisi financial distress akan meningkatkan motivasi manajer terhadap perlakuan manajemen laba (Agrawal dan Chatterjee 2015). Prediksi kondisi financial distress memiliki dampak yang besar bagi perusahaan maupun pihak yang terakit sehingga menyebabkan topik ini menarik banyak peneliti (Wanke et al, 2015). Terdapat lima model yang pada umumnya dipakai untuk prediksi kondisi financial distress. Dalam penelitian Ashraf et al (2019) yang membandingkan kelima model pada perusahaan Pakistan diantaranya: Altman (1968) menggunakan teknik multiple discriminant analysis dengan model Z-score, Ohlson (1980) menggunakan teknik logit dengan model O-score, Zmijewski (1984) menggunakan teknik dan model probit, Shumway (2001) menggunakan teknik dan model hazard dan Blums (2003) menggunakan teknik logit dengan model D-score, menunjukkan bahwa keakuratan prediksi kondisi financial distress dengan model probit dari Zmijewski (1984) lebih akurat daripada empat model lainnya. Hasil yang serupa juga didapat dari penelitian oleh Wu et al (2010) yang membandingkan kelima model prediksi kondisi financial distress pada perusahaan di Amerika Serikat. Pada penelitian ini peneliti memprediksi financial distress dengan model Zmijewksi yang paling akurat agar bisa membuktikan adanya hubungan peningkatan terhadap earnings management. Untuk itu, rumusan masalah pada penelitian ini yaitu:

1. Apakah Opportunistic behaviour meningkatkan motivasi manajer melakukan Earnings Management?

2. Apakah Leverage meningkatkan motivasi manajer melakukan Earnings Management?

\subsection{Tujuan Penelitian}

Mengacu pada penelitian yang dilakukan oleh Ghazali (2015), penelitian menguji sejauh mana opportunistik behavior, leverage dan kondisi financial distress dapat meningkatkan motivasi manajer untuk melakukan earnings management. Data yang digunakan pada penelitian ini berasal dari perusahaan non-keuangan yang tercatat di BEI 
periode 2010-2019 dengan analisis hasil menggunakan regresi linear berganda. Hasil yang diharapkan dapat memberikan bukti secara empiris terkait dengan perilaku manajer dalam mengambil keputusan, khususnya terkait dengan kebijakan akuntansi dengan menggunakan rentan periode yang panjang, agar dapat menangkap fenomena perilaku manajer

\subsection{Telaah Literatur}

\subsubsection{Agency Theory}

Menurut Jensen dan Meckling (1976), teori keagenan membahas mengenai permasalahan yang terjadi di perusahaan dengan adanya antara prinsipal dan agen. Pada umumnya, hubungan itu adalah antara para pemilik saham perusahaan sebagai prinsipal dan agennya adalah manajer perusahan. Hubungan tersebut terkait dengan kontrak antara kedua pihak yang memiliki pertanggungjawaban masing-masing. Sebagai prinsipal memiliki kewajiban penyedia fasilitas dan sumber dana untuk dapat mengelola perusahaannya, sedangkan kewajiban yang dimilki oleh agen yaitu mengelola kinerja perusahaan untuk memenuhi keinginan para pemegang saham. Setelah kedua pihak melakukan tanggung jawab masing-masing, sebagai prinsipal memperoleh pembagian laba, sedangkan agen mendapat gaji dan bonus (Panda dan Leepsa, 2017).

Teori ini menyatakan bahwa agency problem dapat menimbulkan konflik antara kedua pihak. Masalah dapat muncul dikarenakan kedua pihak antara para manajer perusahaan maupun pemegang saham memiliki sifat dasar untuk terlebih dahulu mementingkan dirinya sendiri (Zogning 2017). Konflik yang terjadi diakibatkan karena pemegang saham memiliki ekspektasi untuk mendapatkan jumlah pendapatan yang banyak dengan waktu yang singkat, sedangkan ketika pemegang saham mendelegasikan tanggung jawab untuk pengambilan sebuah keputusan kepada manajer, manajer cenderung termotivasi menggunakan kekuatan tersebut untuk kepentingan sendiri daripada mengambil tindakan untuk mencapai ekspektasi kepentingan pemegang saham.

\subsubsection{Earnings Management}

Manajemen laba (earnings management) terjadi ketika manajer perusahaan memiliki peluang untuk mementingkan kepentingannya sendiri dengan cara merekayasa laporan keuangan (Suffian et al. 2015). Dibalik perlakuan manajemen laba, terdapat motivasi yang mendorong manajer yaitu sifat opportunistic behaviour yang dimiliki seorang manajer untuk hanya memikirkan kepentingan diri sendiri (Healy dan Wahlen 1999). Manajer cenderung mengubah informasi pada laporan keuangan agar mencerminkan perusahaan seolah-olah kinerjanya baik yaitu dengan menunda kerugian dan meningkatkan laba. Rekayasa angka laba menjadi lebih tinggi akan meningkatkan keinginan investor untuk menanamkan modal ke perusahaan karena dipandang bahwa perusahaan memilki prospek masa depan yang terjamin sehat. Selama bertahun-tahun, kualitas dari laporan keuangan perusahaan selalu menjadi pusat perhatian terutama setelah terjadinya kasus Enron yang telah berhasil melakukan manipulasi dalam laporan keuangannya. Kumar dan Vij (2017). Manajer perusahaan yang sengaja melakukan manajemen laba merupakan tindakan kecurangan. Hasil dari perlakuan manajemen laba mengakibatkan kualitas laporan keuangan yang dilaporkan tidaklah akurat dan mengurangi transparansi (Mohd Taufik et al 2015).

\subsubsection{Opportunistic Behavior}

Menurut Jensen (1986), tingginya jumlah arus kas bebas (free cash flow) perusahaan memberikan kesempatan bagi manajer dapat melakukan tindakan manajemen laba atas pendapatan yang juga berhubungan dengan agency theory. Free cash flow didefinisikan dengan jumlah kas sisa yang diperoleh perusahaan setelah dipakai dalam pembiayaan seluruh 
operasional juga pengeluaran wajib. Perusahaan yang memiliki free cash flow yang tinggi menunjukkan bahwa perusahaan semakin sehat (Nazalia dan Triyanto 2018). Free cash flow yang tinggi memberikan manajer perusahaan memiliki dua pilihan antara investasi ke perusahaan yang memiliki kinejra rendah atau tinggi, apabila manajer memilih investasi ke perusahaan yang memiliki kinerja yang rendah maka akan menimbulkan agency theory karena telah mengabaikan tujuan memaksimalkan laba bagi para pemegang saham. Motivasi manajer untuk melakukan perilaku oportunistik juga dikaitkan dengan profitability yang dapat dijelaskan dengan agency theory. Jensen dan Meckling (1976). Profitabilitas perusahaan cenderung menjadi pusat perhatian penilaian. Tingkat profitabilitas menunukkan kemampuan perusahaan dalam memperoleh laba (Tala dan Karamoy 2017). Ketika laba perusahaan mengalami penurunan berarti kinerja perusahaan tidak maksimal, maka dari itu seorang manajer yang oportunistik termotivasi untuk melakukan earnings management untuk menyembunyikan kinerjanya.

\subsubsection{Leverage}

Tingkat leverage yang tinggi cenderung menimbulkan konflik antara pemegang saham dengan para manajer perusahaan dalam pemilihan investasi. Perusahaan memanfaatkan leverage sebagai mekanisme pemantauan dari eksternal yaitu kreditor untuk mengawasi perlakuan manajemen laba. Namun, perusahaan yang mempunyai tingkat jumlah yang tinggi pada leverage memiiki rersiko kebangkuran yang dihadapi juga semakin tinggi karena mengalami kegagalan bayar pembiayaan eksternal (hutang) (Lisboa 2017) Manajer perusahaan akan mencari sumber hutang dengan melakukan manajemen laba.

\subsubsection{Financial Distress}

Terdapat beberapa faktor penyebab terjadinya financial distress Bisgono dan De Luca (2015) yaitu faktor kondisi pertama, perusahaan tidak memiliki kemampuan yang maksimal dalam mengelola pengaliran dana yang diterima dari penjualan dengan pengeleuaran yang diperlukan untuk operasional perusahaan. Kondisi tersebut menyebabkan dana perusahaan tidak cukup atau sering diketahui sebagai tidak likuid. Faktor kondisi kedua yaitu ketika perusahaan tidak dapat membayar hutangnya dikarenakan tingkat hutang yang dimiliki perusahaan tinggi. Pada saat waktu untuk membayar hutang, perusahaan tidak sanggup membayarnya akan mengakibatkan tinggi kemungkinan terjadi financial distress yang berujung kebangkrutan. Faktor kondisi terakhir berhubungan dengan kerugian, apabila perusahaan bertahun-tahun mengalami kerugian. Kondisi tersebut menyebabkan arus kas negatif dan terjadi financial distress. Faktor penyebab terjadinya financial distress memotivasi perusahaan melakukan berbagai cara untuk menghindari kondisi tersebut salah satu nya dengan meningkatkan kemampuan terhadap laba dan mengelola keseimbangan antara penadapatan, pengeluaran maupun hutang agar terhindar dari financial distres.

\subsection{Pengembangan Hipotesis}

\subsubsection{Opportunistic Behavior memengaruhi meningkatnya motivasi manajer terhadap praktik earnings management}

Sifat oportunistik dalam diri seorang manajer akan melakukan kegiatan yang menguntungkan dirinya sendiri tanpa memikirkan pihak lain. Salah satu caranya yaitu dengan mengelola angka pada laporan keuangan agar kinerja buruk perusahaan dapat disamarkan dan melaporkannya seolah perusahaan memiliki kinerja yang baik. Pada penenlitian ini, peneliti membahas sifat oportunistik manajer perusahaan yang dikaitkan dengan free cash flow ataupun profit perusahaan. Free cash flow yang berlebih ataupun profit perusahaan yang 
tinggi menimbulkan peluang untuk para manajer perusahaan dapat mengelola pendapatan dan juga berkaitan dengan agency theory.

Pada awalnya, arus kas sebuah perusahaan digunakan untuk kegiatan yang dapat memberikan nilai yang baik kepada perusahaan. Peluang yang dimiliki manajer perusahaan yang oportunistik menimbulkan masalah keagenan dengan termotivasi melakukan manajemen laba yaitu mengambil keputusan dalam menginvestasi ke perusahaan yang memiliki kinerja rendah. Ghazali, et al (2015). Dampak investasi tersebut akan memberikan kerugian atau menurunkan pendapatan terhadap perusahaan di masa berikutnya. Keadaan tersebutlah yang memotivasi manajer melakukan manajemen laba dengan meningkatkan laba dalam laporan keuangan secara diam-diam. Pendapat tersebut juga didukung oleh penelitian Suffian, et al (2015), Ghazali, et al (2015) dan Rahmawati (2020).

Menurut penelitian yang dilakukan oleh Hasty dan Herawaty (2017), Gunawan et al (2015), dan Dayamanti et al (2018) perusahaan yang memiliki free cash flow yang tinggi ataupun profitabilitas yang baik mencerminkan perusahaan memiliki kinerja yang baik dalam kemampuannya untuk memperoleh laba bersih dari penjualan. Laba yang tinggi dimiliki perusahaan akan cenderung mengurangi motivasi manajer memiliki sifat oportunistik untuk melakukan manajemen laba karena tidak ada hal yang perlu diubah atau disamarkan. Laba perusahaan juga merupakan pusat perhatian dari para pemangku kepentingan, dengan demikian mengurangi para manajer yang oportunistik dalam melakukan manajemen laba. Berdasarkan uraian di atas, hipotesis dapat dirumuskan sebagai berikut:

\section{H1a: Free Cash Flow berpengaruh negatif terhadap Earnings Management H1b: Profitability berpengaruh negatif terhadap Earnings Management}

\subsubsection{Leverage memengaruhi meningkatnya motivasi manajer terhadap praktik earnings management}

Leverage yang dimiliki pada perusahaan mengacu pada aset dan operasi perusahaan yang dibiayai dengan jumlah hutang selain ekuitas. Tingkat leverage yang tinggi pada perusahaan akan memicu risiko kebangkrutan pada perusahaan juga semakin tinggi dikarenakan perusahaan mengalami kegagalan dalam membayar hutangnya ke pihak pemberi pinjaman (Mahawyahrti dan Budiasih 2016). Keadaan tersebut akan mengancam kondisi perusahaan di masa yang akan datang, karena laporan kinerja perusahaan yang buruk menyulitkan untuk mendapatkan dana pinjaman dari pihak eksternal yang baru. Pemberi pinjaman akan menuntut perusahaan apabila perusahaan yang memiliki leverage yang tinggi memiliki motivasi dalam mencari pinajam dari pihak ekternal yang baru.

Keadaan tersebut memberikan tekanan bagi manajer sehingga para manajer perusahaan termotivasi melakukan manajemen laba, dengan memilih metode akuntansi dan estimasi dalam mengelola laba. Manajemen laba yang dilakukan dapat meningkatkan laba agar perusahaan terlihat memiliki kinerja yang baik dengan batas hutang yang wajar sehingga meningkatkan peluang bagi perusahaan untuk mendapat pinjaman baru. Hasil penelitian Ghazali et al (2015), Suffian et al (2015), Anggraeni dan Wardhani (2017) mendapati bahwa leverage memengaruhi peningkatan peluang manajer untuk melakukan Earning Management.

Disisi lain, kegiatan yang oportunistik dapat berkurang dikarenakan adanya leverage, karena pemantauan dari pemberi pinjaman akan mempersempit manajer melakukan manajemen laba dari segi mengambil keputusan dalam investasi. Perusahaan yang memiliki leverage akan mengurangi ketersediaan kas pada perusahaan, sehingga mengurangi peluang untuk manajer perusahaan melakukan manajemen laba. Pendapat tersebut didukung oleh hasil penelitian Karamoy dan Tala (2017), Noor et al (2015) dan Gunawan, et al (2015). Namun, argumen pada penelitian ini cenderung melihat bahwa perusahaan yang memiliki leverage 
yang semakin tinggi, justru akan memotivasi manajer untuk melakukan earnings management agar dapat menjaga stabilitas kinerja perusahaan dimata pihak ketiga. Sehingga hipotesis dapat dirumuskan sebagai berikut:

H2: Leverage berpengaruh positif terhadap perlakuan Earning Management.

\subsubsection{Financial Distress memengaruhi meningkatnya motivasi manajer terhadap praktik earnings management}

Perusahaan yang mengalami financial distress menunjukkan keadaan perusahaan yang sedang tidak baik dan memiliki kesulitan dalam memenuhi kewajiban perusahaan. Keadaan tersebut dapat memberikan kondisi perusahaan dinilai memiliki persentase kebangkrutan yang lebih tinggi. Ghazali, et al (2015) mendefinisikan bahwa perusahaan yang mengalami financial distress menunjukkan bahwa kondisi perjanjian dengan para kreditur berada pada tahap yang sulit dimana perusahaan tertekan juga tertekan dalam melunasi kewajibannya yang lebih tinggi dibandingkan total asetnya. Kondisi tersebut menyimpulkan bahwa operasional perusahaan dalam keadaan yang tidak baik dan apabila tidak dikendalikan akan menyebabkan kebangkrutan.

Kondisi perusahaan yang tertekan akan mengalami kebangkrutan, manajer pada perusahaan cenderung termotivasi menggunakan manajemen laba untuk mengelola laba yang dilaporkan pada laporan keuangan. Selain itu, Manajer pada perusahan yang mengalami financial distress juga akan mengasumsikan bahwa pendapatan bonus mereka akan terpotong. Para manajer perusahaan termotivasi untuk memanipulasi laporan keuangaan dengan meningkatkan laba agar kinerja perusahaan yang buruk seolah-eolah terpandang baik dari pihak luar (Chatterjee 2015). Penelitian sebelumnya juga mendukung bahwa ketika perusahaan megalami financial distress memengaruhi peningkatan motivasi untuk mengabarkan informasi kabar baik ke pasar modal agar nilai perusahaan tetap stabil (Damayanti dan Kawedar 2018, Li et al. 2020)

Menurut hasil penelitian Ghazali, et al (2015) bahwa financial distress tidak memengaruhi earning management dikarenakan para manajer telah memperlakukan manajemen laba sebelum terjadinya kesulitan keuangan. Ketika perusahaan telah mengalami kesulitan keuangan, para manajer telah tidak memiliki cara yang lain untuk memanipulasi ataupun mengelola laba karena mereka telah gagal untuk memanfaatkan manajemen laba tersebut. Pernyataan tersebut juga didukung oleh penelitian Yolanda et al. (2019). Para manajer juga akan memikirkan kembali untuk melakukan manajemen laba karena apabila perusahaan sedang dalam kondisi financial distress dan melakukan manajemen laba dianggap akan memberikan kerugian dikedepannya.

Perusahaan juga akan mempertimbangkan apabila perlakuan manajemen laba terdeteksi maka kepercayaan yang dimiliki oleh pemangku kepentingan yaitu para pemegang saham akan hilang. Perusahaan yang sedang mengalami financial distress dan juga telah memiliki reputasi dalam melakukan kinerja manajemen laba akan membuat para investor untuk tidak melakukan investasi pada perusahaan tersebut. Kondisi tersebut akan mempersulit perusahaan untuk memperbaiki kondisi kesulitan keuangannya dikarenakan tidak memiliki modal yang mencukupi. Manajer perusahaan lebih memilih untuk melaporkan laporan keuangan sesungguhnya daripada melakukan manajemen laba. Berdasarkan uraian di atas, hipotesis dapat dirumuskan sebagai berikut:

H3: Financial Distress berpengaruh positif terhadap Earning Management 


\section{METODOLOGI DAN ANALISIS DATA \\ 2.1 Subjek dan Objek Penelitian}

Pemilihan sampel penelitian ini dengan metode purposive sampling sesuai dengan kriteria pada Tabel 1. Informasi data keuangan perusahaan dikumpulkan menggunakan situs $S \& P$ Capital IQ. Hasil dari pemilihan sampel dimana dari 314 perusahaan non-keuangan yang terdapat di Bursa Efek Indonesia (BEI), terpilih 232 perusahaan yang sesuai dengan kriteria pada periode 2010-2019.

\section{Tabel 1. Kriteria Sampel Penelitian}

\begin{tabular}{|c|c|}
\hline Keterangan & $\begin{array}{c}\text { Jumlah } \\
\text { Perusahaan }\end{array}$ \\
\hline $\begin{array}{l}\text { Perusahaan nonkeuangan yang terdaftar di } \\
\text { BEI periode } 2010-2019 \text {. }\end{array}$ & 314 \\
\hline $\begin{array}{l}\text { Perusahaan non-keuangan yang mempublikasikan laporan keuangan per } \\
31 \text { Desember pada periode } 2010-2019 \text { secara berturut-turut konsisten. }\end{array}$ & 298 \\
\hline $\begin{array}{l}\text { Perusahaan nonkeuangan yang memiliki } \\
\text { penyajian laporan keuangan dalam mata uang Rupiah }\end{array}$ & 233 \\
\hline $\begin{array}{l}\text { Perusahaan nonkeuangan memiliki data } \\
\text { informasi lengkap untuk diperlukan sebagai variabel penelitian. }\end{array}$ & 232 \\
\hline $\begin{array}{l}\text { Perusahaan yang akan digunakan sebagai } \\
\text { sampel dalam penelitian ini }\end{array}$ & 232 \\
\hline Observasi (232 perusahaan x 10 tahun) & 2320 \\
\hline
\end{tabular}

\subsection{Model Penelitian}

Analisis yang dilakukan pada penelitian ini menggunakan regresi linear berganda dengan bantuan perangkat lunak STATA (versi 16.1) Berikut merupakan model empiris yang digunakan pada penelitian ini untuk menjawab hipotesis penelitian:

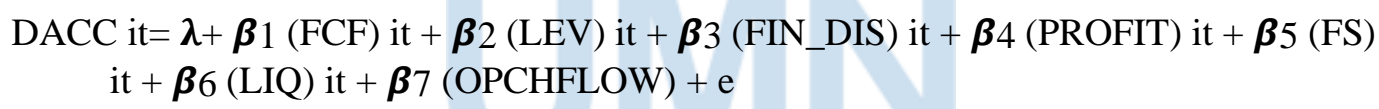

Dimana,

$\begin{array}{ll}\text { DACC } & : \text { Discretionary accrual } \\ \text { FCF } & : \text { Free Cash Flow } \\ \text { LEV } & : \text { Debt Ratio } \\ \text { FIN_DIS } & : \text { Dummy variabel, 1 jika perusahaan mengalami financial distress, } 0 \\ & \text { lainnya. } \\ \text { PROFIT } & : \text { Return on Assets } \\ \text { FS } & : \text { Ukuran Perusahaan (Ln Total Assets) } \\ \text { LIQ } & : \text { Current Ratio } \\ \text { OPCSHFLOW } & : \text { Perating Cash Flow }\end{array}$

\subsection{Penelitian}

\subsubsection{Variabel Dependen}

Variabel dependen yang diuji adalah earnings management. Penelitian ini menggunakan model Kothari (2005), karena model tersebut merupakan penyempurnaan dari model Jones dengan menambahkan return on assets (ROA) dalam perhitungan akrual 
diskresioner. ROA dapat meminimalkan kesalahan secara spesifik sehingga menimbulkan hasil yang lebih akurat terhadap manajemen laba.

\subsubsection{Variabel Independen}

\section{Free Cash Flow}

Pengukuran terhadap free cash flow digunakan untuk mengetahui sisa kas yang tersedia oleh perusahaan setelah memperhitungkan arus kas keluar untuk menjalankan operasional perusahaan. Pada penelitian ini mengukur free cash flow menggunakan metode Lehn \& Poulsen (1989) dengan menggunakan komponen diantaranya income, income tax, interest expense, total amount of preference dividend dan total amount of common dividend.

\section{Leverage}

Rasio Leverage digunakan sebagai pengukuran terhadap seberapa besar sebuah perusahaan mengoperasionalkan perusahannya menggunakan utang. Pada penelitian ini rasio leverage sebagai monitoring mechanism perusahaan melakukan manajemen laba, rasio pengukuran yang digunakan yaitu debt ratio.

\section{Financial Distress}

Kondisi perusahaan yang mengalami financial distress merupakan kondisi krusial karena perusahaan sedang mengalami kesulitan keuangan yang dapat menyebabkan kebangkrutan. Pada penelitian ini, pegukuran financial distress menggunakan model Zmijewski (1984) yang diukur dengan variabel dummy. Menurut penelitian Ashraf et. al (2019) yang membangdingkan kelima model deteksi financial distress, model probit dari Zmijewski (1984) lebih akurat daripada empat model lainnya. Model rumus Zmijewski (1984) sebagai berikut:

$\mathrm{ZFS}=-4.336-4.513(\mathrm{X} 1)+5.679(\mathrm{X} 2)-0.004(\mathrm{X} 3)$

Keterangan:

$\mathrm{X} 1=$ Net Income/ Total Assets

$\mathrm{X} 2=$ Total Debt/Total Assets

$\mathrm{X} 3=$ Current Assets/Current Liabilities

Pengukuran financial distress kemudian diproksikan menjadi variabel dummy, yaitu 1 apabila nilai ZFS lebih besar dari nol yang artinya perusahaan mengalami financial distress, dan sebaliknya apabila perusahaan tidak mengalami financial distress maka nilai ZFS akan lebih kecil dari nol sehingga dinyatakan dengan angka 0 .

\section{Ukuran Perusahaan}

Ukuran perusahaan (firm size) adalah perhitungan untuk mengetahui seberapa besar kecilnya skala perusahaan. Semakin besar ukuran sebuah perusahaan maka peluang manajer dalam melakukan manajemen laba perusahaan juga semakin besar

\section{Likuiditas}

Likuiditas (liquidity) adalah penilaian perusahaan dalam kemampuannya untuk memiliki aset lancar yang dapat membayarkan kewajibannya. Rendahnya tingkat likuiditas yang dimiliki perusahaan memotivasi manajer perusahaan melakukan earnings management agar operasional perusahaan seperti memilki kemampuan kinerja yang baik.

\section{Operating Cash Flow}

Operating Cash Flow merupakan kas yang dihasilkan dari operasi atau aktivitas perusahaan secara normal. OCF tersebut menunjukkan penilaian pada perusahaan apakah menghasilkan arus kas yang cukup untuk menjalankan bisnisnya dan 
megembangkan operasinya. Dalam penelitian ini, Operating Cash Flow dihitung dengan Income from Operation diskalakan dengan Total Aset

\section{HASIL PENELITIAN DAN DISKUSI}

\subsection{Statistik Deskriptif}

Tabel 2 menunjukkan hasil statistik dengan variabel DACC memiliki nilai minimum negatif $(-8,2002)$, dan nilai maksimum 24,8 . Nilai rata-ratanya negatif sebesar $(-0,0081529)$ yang berarti bahwa perusahaan bertujuan untuk melakukan manajemen laba dengan 1105 perusahaan melakukan income decreasing.

Tabel 2. Deskriptif Statistik

\begin{tabular}{cccccc}
\hline Variable & Obs & Mean & Std. Dev. & Min & Max \\
\hline DACC & 2,320 & $-0,0081529$ & 0,6723772 & $-8,2002$ & 24,8 \\
\hline FCF & 2,320 & 0,0615635 & 0,1774244 & $-2,7275$ & 2,9972 \\
\hline LEV & 2,320 & 0,2597046 & 0,3650318 & 0 & 7,7123 \\
\hline FIN_DISTRESS & 2,320 & 0,0741379 & 0,2620517 & 0 & 1 \\
\hline PROFIT & 2,320 & 4,782954 & 5,108013 & $-4,213$ & 16,3895 \\
\hline FS & 2,320 & 14,52134 & 1,82582 & 8,5611 & 19,679 \\
\hline LIQ & 2,320 & 2,246548 & 1,904771 & 0,41165 & 7,8022 \\
\hline OPCSHFLOW & 2,320 & 0,651713 & 0,1138449 & $-0,8905$ & 1,1266 \\
\hline
\end{tabular}

Sumber: Data diolah (2020)

FCF yang memiliki nilai minimum negatif $(-2,7275)$ dan nilai maksimum sebesar 2,9972. Rata-rata FCF sebesar 0,0615635 yang menunjukkan bahwa rata-rata perusahaan memiliki nilai positif. Dari hasil total hasil observasi terdapat 1795 perusahaan yang memiliki sisa kas yang tersedia oleh perusahaan setelah memperhitungkan arus kas keluar untuk menjalankan operasional perusahaan.

FIN_DISTRESS menggunakan penilaian dummy sehingga memiliki nilai minimum sebesar 0 dan nilai maksimum sebesar 1. Rata-rata FIN_DISTRESS sebesar 0,0741379 menunjukkan rata-rata perusahaan sebesar $7,41 \%$ perusahaan dalam sampel dikategorikan dalam keadaan sehat. Dari hasil observasi menggunakan Zmijewski terdapat 2148 perusahaan yang dikategorikan dalam keadaan sehat dan sisanya sebanyak 172 perusahaan yang dikategorikan memiliki financial distress.

PROFIT memiliki nilai minimum negatif $(-4,213)$ dan nilai maksimum 16,3895 . Dari hasil observasi pada penelitian ini terdapat 357 perusahaan yang negatif berarti perusahaan mengalami net loss dan sisanya sebanyak 1963 perusahaan yang positif berarti perusahaan memiliki income. Secara keseluruhan dari hasil rata-rata variabel PROFIT sebesar 4,782954 yang menunjukkan bahwa hasil nilai $R O A$ positif berarti rata-rata perusahaan memiliki income lebih besar daripada total assets.

Variabel control firm size, liquidity dan operation cash flow. Firm size yang diproksikan menggunakan In total asset memiliki nilai minimum 8,5611, nilai maksimum 19,679 dan nilai rata-rata sebesar 14,52134. Liquidity memiliki nilai minimum 0,41165 dan nilai maksimum 7,8022 dengan nilai rata-rata 2,246548 yang berarti dari keseluruhan observasi perusahaan memiliki sifat likuiditas yang lancar. Operation cash flow memiliki nilai minimum $(-0,8905)$ dan nilai maksimum 1,1266. Dari hasil observasi sebanyak 1788 perusahaan mengalami income dan sisanya 532 perusahaan mengalami operating loss. Nilai rata-rata operation cash flow 0,0651713 bernilai positif yang berarti secara keseluruhan perusahaan mengalami income yang dihasilkan dari total aset. 


\subsection{Pembahasan Hipotesis}

Berdasarkan tabel 3, nilai p-value menggunakan one-tailed menunjukkan bahwa variabel FCF dan Profit berpengaruh signifikan pada level 0,05, leverage signifikan pada level 0,05 sedangkan variabel financial distress tidak memiliki pengaruh yang signifikan terhadap variabel dependen earnings management (DACC). Free cash flow dan leverage memiliki arah yang positif sedangkan financial distress dan profitability memiliki arah yang negatif terhadap earnings management.

Tabel 3. Hasil Pengujian

\begin{tabular}{|c|c|c|c|c|c|c|}
\hline Source & s5 & $d f$ & MS & Number of obs & $=$ & 2,320 \\
\hline Mode 1 & 26.6028396 & 7 & 3.80040565 & Prob $>F$ & $=$ & 0.0000 \\
\hline Residual & 1021.79679 & 2,312 & .441953629 & R-squared & $=$ & 0.0254 \\
\hline Total & 1048.39963 & 2,319 & .452091259 & Root MSE & $=$ & .6648 \\
\hline
\end{tabular}

\begin{tabular}{r|rrrrrr}
\hline dacc & Coef. & Std. Err. & $t$ & $P>|t|$ & \multicolumn{2}{r}{ [95\% Conf. Interval] } \\
\hline fcf & .2157945 & .102041 & 2.11 & 0.035 & .0156931 & .4158959 \\
lev & .0822072 & .0432706 & 1.90 & 0.058 & -.002646 & .1670605 \\
fin_distress & -.0448237 & .0592957 & -0.76 & 0.450 & -.161102 & .0714546 \\
profit & -.0082138 & .0038241 & -2.15 & 0.032 & -.0157129 & -.0007147 \\
fs & .0445499 & .0079644 & 5.59 & 0.000 & .0289317 & .0601681 \\
liq & .0258644 & .0078451 & 3.30 & 0.001 & .0104803 & .0412485 \\
opcshflow & -.5349092 & .1508911 & -3.55 & 0.000 & -.8308053 & -.239013 \\
_cons & -.6703471 & .1204315 & -5.57 & 0.000 & -.9065122 & -.434182 \\
\hline
\end{tabular}

\subsubsection{Pengaruh Opportunistic Behavior terhadap Earnings Management}

Hipotesis pertama (H1a dan $\mathrm{H} 1 \mathrm{~b})$ pada penelitian ini adalah manajer perusahaan yang memiliki kinerja yang baik, yang diukur dengan free cash flow dan profitabilitas, akan mengurangi motivasi manajer untuk melakukan earnings management. Hasil pengujian hipotesis 1a memiliki signifikansi kurang dari 0,05 namun hasil koefisien regresinya positif yang artinya tidak sesuai dengan hipotesis. Sehingga dapat dikatakan bahwa hasil tidak mendukung hipotesis 1a yaitu free cash flow berpengaruh positifterhadap earnings management. Hasil ini bertolak belakang dengan temuan Ghazali et al. (2015) yang mendapati bahwa free cash flow justru berpengaruh negatif terhadap earnings management dibandingkan dengan profitabilitas. Hasil ini juga tidak mendukung penelitian yang dilakukan oleh Suffian, et al (2015) dan Rahmawati (2020). Setiap manajer perusahaan memiliki pilihan untuk memilih dimana dana tersebut mau diinvestasikan. Free cash flow perusahaan yang berlebih dapat memotivasi para manajer untuk diinvestasi ke perusahaan yang memiliki kinerja yang rendah, sehingga efek dari keadaan tersebut dapat menurunkan pendapatan pada perusahaan. Akibatnya akan meningkatkan perlakuan sifat oportunistik para manajer untuk melakukan earnings management agar tetap dapat melaporkan kinerja yang baik pada laporan keuangan perusahaan.

Hasil pengujian hipotesis pertama didukung hanya dari sisi Profitabilitas (H1b) karena hasil yang diperoleh menunjukkan tingkat signifikansi lebih kecil dari 0,05 dan arah yang sesuai dengan hipotesis. Profitabilitas yang tinggi dapat mengurangi perlakuan sifat 
oportunistik manajer dalam melakukan earnings management. Hasil tersebut menunjukkan hipotesis $1 \mathrm{~b}(\mathrm{H} 1 \mathrm{~b})$ diterima, dimana profitabilitas berpengaruh negatif terhadap earnings management. Hasil penelitian ini bertolak belakang dengan penelitian Ghazali et al. (2015) yang justru mendapati bahwa profitabilitas memiliki pengaruh positif terhadap earnings management, sebaliknya hasil ini mendukung penelitian yang dilakukan oleh Hasty dan Herawaty (2017), Gunawan et al (2015) dan Dayamanti et al (2018). Berdasarkan hasil ini, perusahaan yang memiliki profitabilitas yang baik mencerminkan bahwa keadaan kinerja perusahaan baik dalam mengelola laba perusahaan. Sehingga dapat disimpulkan bahwa laba yang tinggi tidak memotivasi para manajer untuk memiliki sifat oportunistik melakukan earnings management karena tidak ada permasalahan lagi yang perludiubah.

\subsubsection{Pengaruh Leverage terhadap Earnings Management}

Hasil pengujian hipotesis leverage lebih dari 0,05 namun dikarenakan hipotesis mengacu pada pengujian one-tailed, maka hasil yang diperoleh menjadi 0,029 . Sehingga nilai yang diperoleh pada pengujian ini menunjukkan bahwa leverage berpengaruh positif dan signifikan terhadap earnings management. Artinya, leverage dapat meningkatkan motivasi manajer dalam melakukan earnings management. Hasil penelitian ini menerima hipotesis 2 (H2) yang menyatakan bahwa leverage berpengaruh positif terhadap perlakuan earning management. Hasil penelitian ini mendukung hasil penelitian yang dilakukan oleh Noor et al (2015) dan Gunawan, et al (2015) yang menjelaskan bahwa perusahaan yang banyak menggunakan hutang dalam mengoperasionalkan perusahaannya, meningkatkan motivasi para manajer perusahaan untuk melakukan earnings management. Hasil penelitian ini bertolak belakang dengan hasil penelitian yang dilakukan Ghazali, et al (2015), Suffian, et al (2015) dan Wardhani (2017).

Tingkat leverage yang tinggi menunjukkan bahwa sebagian besar pendanaan perusahaan berasal dari hutang dari pihak luar yang berarti aktivitas pemasukkan dan pengeluaran termonitor dari para pemberi pinjaman. Hal ini membuat manajer berada dalam tekanan untuk menjaga kinerja perusahaan tetap dalam kondisi stabil, sehingga kesepakatan dengan pihak ketiga yang mengontrol kinerja mereka tetap berjalan dengan baik. Keadaan inilah yang dapat memotivasi manajer perusahaan untuk membuat laporan keuangan terlihat lebih baik agar pihak kreditor menilai bahwa perusahaan memiliki kemampuan untuk menghasilkan laba yang dapat melunasi hutangnya.

\subsubsection{Pengaruh Financial Distress terhadap Earnings Management}

Hasil pengujian financial distress menunjukkan nilai $p$-value lebih dari 0,05 dengan arah koefisien negatif. Hasil penelitian ini menolak hipotesis $3(\mathrm{H} 3)$ yaitu financial distress berpengaruh positif terhadap earning management. Hasil penelitian ini mendukung hasil penelitian yang dilakukan oleh Ghazali, et al (2015), yang menjelaskan bahwa keadaan perusahaan yang sedang mengalami financial distress tidak meningkatkan peluang manajer perusahaan untuk melakukan earnings management. Hasil penelitian ini bertolak belakang dengan hasil penelitian yang dilakukan Chatterjee (2015), Damayanti dan Kawedar (2018), dan Li et al (2020).

Chan dan Chen (1991) mendefinisikan financial distress merupakan kondisi perusahaan yang sedang mengalami tekanan aliran uang akibat dari permasalahan terhadap arus kas perusahaan dimana kondisi tersebut dinilai kompleks. Dari hasil penelitian yang menyatakan keadaan financial distress tidak signifikan berarti kondisi financial distress tidak memengaruhi manajer untuk melakukan manajemen laba. Kecenderungan manajer melakukan manajemen laba tidak ditentukan dengan kondisi financial distress perusahaan. 
Dalam kondisi apapun yaitu dalam kondisi perusahaan sehat ataupun mengalami financial distress manajemen perusahaan tetap bisa melakukan manajemen laba

\section{KESIMPULAN DAN SARAN}

\subsection{Kesimpulan}

Penelitian ini menguji pengaruh opportunistic behavior (yang diukur menggunakan free cash flow dan profitability), leverage, dan financial distress terhadap earnings management. Hasil penelitian ini menyimpulkan bahwa Opportunistic Behaviour yang diproksikan melalui Free cash Flow dan Profitability, hanya dapat dibuktikan oleh profitability yang berpengaruh negatif dan signifikan, sedangkan free cash flow menunjukkan arah yang sebaliknya. Hasil ini berbanding terbalik dengan penelitian Ghazali et al. (2015) yang menemukan free cash flow berpengaruh negatif, sedangkan profitability menunjukkan hasil yang positif. Leverage menunjukkan hasil yang positif terhadap earnings management sesuai dengan prediksi. Sementara itu, berbeda dengan temuan Ghazali et al. (2015), Financial Distress tidak berpengaruh secara signifikan terhadap earnings management. Implikasi dari hasil penelitian menunjukkan adanya motivasi tertentu yang berpengaruh pada perilaku manajer dalam mengambil keputusan terutama yang menyangkut kebijakan akuntansi. Temuan ini juga menunjukkan bahwa kecenderungan informasi yang menjadi fokus manajer adalah profitabilitas dan hutang. Khususnya di Indonesia, investor dan kreditor perlu untuk mengamati informasi lain selain profitabilitas perusahaan dalam mengevaluasi dan memonitor kinerja perusahaan sebelum mengambil keputusan dalam berinvetasi, maupun melakukan pendanaan. Fokus berikutnya adalah pada perusahaan yang memiliki nilai hutang yang cukup tinggi, karena kemungkinan besar untuk melakukan earnings management agar kinerjanya terlihat baik. Sedangkan terkait dengan kondisi financial distress, model yang Zmijweski (1984) mungkin belum dapat memprediksi dengan baik data yang digunakan, khususnya di Indonesia. Penelitian berikutnya dapat mencoba model prediksi lainnya yang mungkin lebih dapat menangkap fenomena data perusahaan di Indonesia.

\subsection{Keterbatasan dan Saran}

Pada penelitian ini memiliki beberapa keterbatasan yaitu pertama, hanya menggunakan satu jenis model akrual (Kothari 2005) sedangkan masih banyak model akrual lainnya yang dapat digunakan untuk menghitung akrual diskresioner. Ghazali et al. (2015) berpendapat bahwa penggunaan model akural yang berbeda akan mengurangi kesalahan dalam menghitung akrual diskresioner. Kedua, penelitian ini tidak berfokus pada industri dan ukuran perusahaan tertentu. Penelitian yang memiliki ketentuan tersebut dapat menghasilkan temuan yang berbeda dan konklusif. Peneliti selanjutnya dapat membandingkannya dengan model pengukuran earnings management yang lainnya dan fokus terhadap industri tertentu sehingga hasilnya menjadi lebih mendalam dan konklusif.

\section{REFERENSI}

Agrawal, K., \& Chatterjee, C. (2015). Earnings Management and Financial Distress: Evidence from India. Global Business Review SAGE, 16(5S), 140S-154S. doi:10.1177/09721509

Anggraeni, M. D., \& Wardhani, R. (2017). The Effect of Leverage and IFRS Convergence on Earnings Management Through Real Activities Manipulation in Asia. Asian Journal of Business and Accounting, 10(1), 87- 125. 
Ashraf, S., G. S. Félix, E. dan Serrasqueiro, Z., (2019). Do Traditional Financial Distress Prediction Models Predict the Early Warning Signs of Financial Distress? Journal of Risk and Financial Management, 12(2), p.55.

Bisogno M. and De Luca R. (2015) Financial Distress and Earnings Manipulation: Evidence from Italian SMEs. Journal of Accounting and Finance, 4(1), 042- 051.

Callao, S., I. Jarne, J., \& Wrablewski, D. (2017). Detecting Earnings Management Investigation on Different Models Measuring Earnings Management for Emerging Eastern European Countries, 5(11). doi:10.5281

Chan, K.C. and Chen, N. (1991) Structural and Return Characteristics of Small and Large Firms. Journal of Finance, 46, 1739-1789. https://doi.org/10.1111/j.1540-6261.1991.tb04642.x

Damayanti, C. R., \& Kawedar, W. (2018). Pengaruh profitabilitas, mekanisme pemantauan dan financial distress terhadap manajemen laba. DIPONEGORO JOURNAL OF ACCOUNTING, 7, 1-9.

Ghazali, A. W., Shafie, N. A., \& Sanusi, Z. M. (2015). Earnings Management: An Analysis of Opportunistic Behaviour, Monitoring Mechanism and Financial Distress. Procedia Economics and Finance, 28, 190-201. doi:10.1016/s2212- 5671(15)01100-4.

Gunawan, K., Darmawan, N. A., \& Purnamawati, G. A. (2015). Pengaruh Ukuran Perusahaan, Profitabilitas, dan Leverrage terhadap Manajemen Laba pada Perusahaan Manufaktur yang terdaftar di Bursa Efek Indonesia (BEI). E- Journal S1 Ak Universitas Pendidikan Ganesha, 03.

Healy, P.M., \& Wahlen, J.M. (1999). A review of the earnings management literature and its implications for standard setting. Accounting Horizons, 7(1), 365-383

Jensen, M., \& Meckling, W. (1976). Theory of The Firm: Managerial Behaviour, Agency Costs and Ownership Structure. Jurnal of Financial Economics, 305- 360.

Jensen, M.C. (1986). Agency costs of free cash flow, corporate finance, and takeovers. The American Economics Review, 76(2), 323-329.

Li, Y., Li, X., Xiang, E., \& Djajadikerta, H. G. (2020). Financial distress, internal control, and earnings management: Evidence from China. Journal of Contemporary Accounting \& Economics, 16(3), 100210. doi:10.1016/j.jcae.2020.100210.

Lisboa, I. (2017). Impact of financial crisis and family control on earning management of Portuguese listed firms. European Journal of Family Business,6(2), 118-131. doi:10.1016/j.ejfb.2017.06.002

Mahawyahrti, P. T., \& Budiasih, I. A. (2016). Asimetri Informasi, Leverage, dan Ukuran Perusahaan pada Manajemen Laba. Jurnal Ilmiah Akuntansi Dan Bisnis, 11, 100-110. doi:https://doi.org/10.24843/JIAB.2016.v11.i02.p05.

Mohd Taufik, M. S., Zuraidah, M. S. \& Nor'Azam, M. (2015). Real Earnings Management and Firm's Value: Empirical Evidence from Malaysia. Malaysian Accounting Review, 14 (1).

Nazalia, N., \& Triyanto, D. N. (2018). Pengaruh free cash flow, financial distress, dan employee diff terhadap manajemen laba. Jurnal Akutansi, Audit Dan Sistem Informasi Akutansi, 2, 93-103.

Noor, N., Sanusia, Z., Heang, L., Iskandar, T., \& Isa, Y. (2015, October 28). Fraud Motives and Opportunities Factors on Earnings Manipulations, from https://www.sciencedirect.com/science/article/pii/S2212567115010916 
Panda, B., \& Leepsa, N. M. (2017). Agency theory: Review of Theory and Evidence on Problems and Perspectives. Indian Journal of Corporate Governance, 10(1), 74-95. doi:10.1177/0974686217701467

Rahmawati, T. (2020). The Influence of Surplus Free Cash Flow and Audit Quality in Earnings Management. Jurnal Akuntansi \& Ekonomi FE UN PGRI Kediri, 5(2).

Suffian, M. T., Sanusi, Z. M., Osman, A. H., \& Azhari, M. I. (2015). Manipulation of Earnings: The Pressure of Opportunistic Behavior and Monitoring Mechanisms in Malaysian Shariah-compliant Companies. Procedia Economics and Finance, 31, 213227. doi:10.1016/s2212-5671(15)01223-xTala, O., \& Karamoy, H. (2017). Analisis Profitabilitas dan Leverage terhadap Manajemen Laba pada Perusahaan Manufaktur di Bursa Efek Indonesia. Jurnal Accountability, 06, 57-64.

Tala, O., \& Karamoy, H. (2017). Analisis Profitabilitas dan Leverage terhadap Manajemen Laba pada Perusahaan Manufaktur di Bursa Efek Indonesia. Jurnal Accountability, 06, 57-64.

Wanke, Peter, Carlos P. Barros, and João R. Faria. (2015). Financial distress drivers in Brazilian banks: A dynamic slacks approach. European Journal of Operational Research 240, 258-68.

Wu, Y., Clive Gaunt, and Stephen F. Gray. (2010). A comparison of alternative bankruptcy prediction models. Journal of Contemporary Accounting and Economics 6, 34-45.

Yolanda, Mita, Kinanti Woro Hapsari, Suci Nurul Akbar, \& Vinola Herawaty (2019). Pengaruh Kepemilikan Manajerial dan Kualitas Audit Terhadap Earning Management Dengan Financial Distress Sebagai Variabel Intervening Studi Empiris Pada Perusahaan Manufaktur Yang Terdaftar di BEI 2015-2017, Prosiding Seminar Nasional Pakar Ke 2.

Zmijewski, Mark E. (1984). Methodological issues related to the estimation of financial distress prediction models. Journal of Accounting Research 22, 59- 82.

Zogning, F. (2017). Agency Theory: A Critical Review. European Journal of Business and Management, 9(2). 